\title{
The Influence of Symbolic Modeling Technique Guidance Service and Group Guidance Service for Achievment Motivation Based in Anxiety Levels in the Physically Challenged Athletes of North Sumatera PPI NPC
}

\author{
Ahmad Zaki \\ Department of Sport Education \\ Post Graduate Program \\ Universitas Negeri Medan \\ (UNIMED) \\ Medan, Indonesia
}

\author{
Budi Valianto \\ Department of Sport Education \\ Post Graduate Program \\ Universitas Negeri Medan \\ (UNIMED) \\ Medan, Indonesia
}

\author{
Albadi Sinulingga \\ Department of Sport Education \\ Post Graduate Program \\ Universitas Negeri Medan \\ (UNIMED) \\ Medan, Indonesia
}

\begin{abstract}
The aim of the study to find out the influence between symbolic modeling technique service and group guidance services in increasing achievement motivation based on anxiety levels on the physically impaired athletes of North Sumatera PPI NPC. This study used expost facto method. Data collection techniques in this study used a questionnaire and observation. Data analysis techniques using path analysis.The hypotheses on the discussion of this study are:(1)There is no influence of symbolic modeling guidance services (X1) on anxiety (Y), (2) There is an influence of the influence of symbolic modeling guidance services (X1) on Anxiety (Y), (3) There is no influence of group guidance services (X2) on anxiety (Y), (4) There is an influence of group guidance services (X2) on Anxiety (Y), (5) There is no influence of anxiety (Y) on achievement motivation ( $\mathrm{Z}$ ), (6) There is an influence of anxiety (Y) on achievement motivation $(Z)$.
\end{abstract}

Keywords: Guidance Service, Anxiety, Achievement Motivation.

\section{INTRODUCTION}

The highest sports achievements are certainly always coveted by every athlete, especially for athletes who pursue either individually or in groups. To achieve this, the right way to do it is to foster good training and training according to the rules and regulations that apply in practice.

Achievement sports begin with the need and drive in humans to carry out physical activities. Develop functional, skill and speed of body organs. Alternative distribution of moving desires in the form of sports, while one of them is achievement sports. Achievement sports are grouped, among others, sports achievements of normal athletes and sports achievements of athletes with disabilities.
Achieving maximum performance requires optimal, planned and ongoing training factors. As stated by Bompa (1995: 55) "... the stronger the physical foundation, the higher the technical, tactical, and psychological heights". This means that four aspects of training need to be considered and trained carefully by athletes, namely technical training, tactical training, physical training, and mental training.

Harsono (in Gunarsa, 2004: 81) revealed that the peak performance of an athlete $80 \%$ is influenced by mental aspects and only $20 \%$ by other aspects, so mental aspects must be managed intentionally, systematically and planned. However, in Indonesia the psychological aspect has not been much studied and researched while the technical, tactic, physical aspects have been widely studied.

Physical imperfections in certain people so that it becomes a form of deficiency or disability. The emergence of disability can be motivated by health problems arising from birth, chronic diseases or tools, and injuries that can be caused by accidents, war, riots, disasters, and so on. Disability is closely related to physical and mental health, many disabilities are motivated by health problems, and vice versa.

Tunadaksa is a child who has physical, bodily or orthopedic disabilities. The degree of heredity will affect the ability of self-adjustment to the environment that is strongly influenced by the type and degree of heredity. This type of disability can lead to changes in behavior. This type of disability will cause changes in behavior as compensation for deficiencies or disabilities. Judging from the psychological aspect, children who are overweight tend to feel shy, low self- 
esteem, and sensitive, and separate themselves from the environment.

Based on an interview from an athletic trainer at the North Sumatra NPC, Yogi rivai, he stated that athletes' performance has declined due to several things, for example in the athlete's psychic, which is quite influential, especially in the physical classification. Individuals with physical disabilities have less positive experience because they do not have favorable positions in social relations. Then in terms of coaching is also quite good where athletes are fostered with an adjusted time. But there are some aspects that are not affordable by coaches or coaches, namely athlete's psychology. So that it has an impact on athletes' achievements that are found at the time of observation as below:

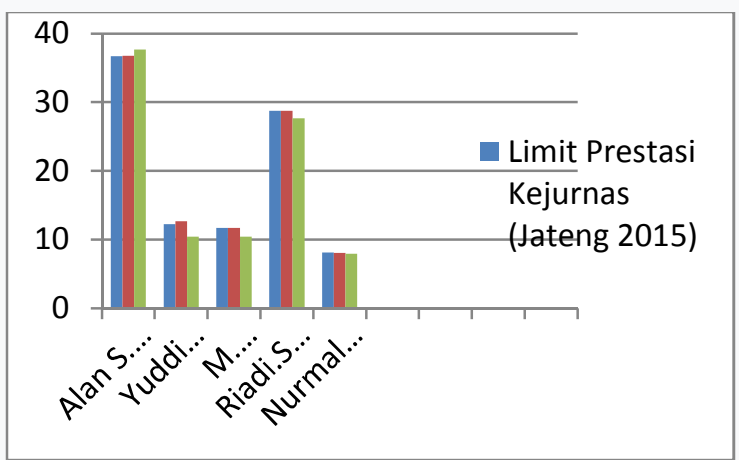

Fig.1. Personal Achievement Data Achievement Number Specialist Field Athletics Tuna daksa NPC North Sumatra.

Observing the data above, personal achievement data is the number of athletic athletes in the North Sumatra NPC classification of athletic athletes who compete in National Championship and Peparnas. The data above shows that there is a decrease in achievement in the number of athletic athletes specialist athletic field numbers who participate in the championship every year.

Furthermore, data from the North Sumatra NPC athletic trainer regarding the personal achievements of athletes in the track race numbers at the national championship (National Championship) from 2015 to 2017.

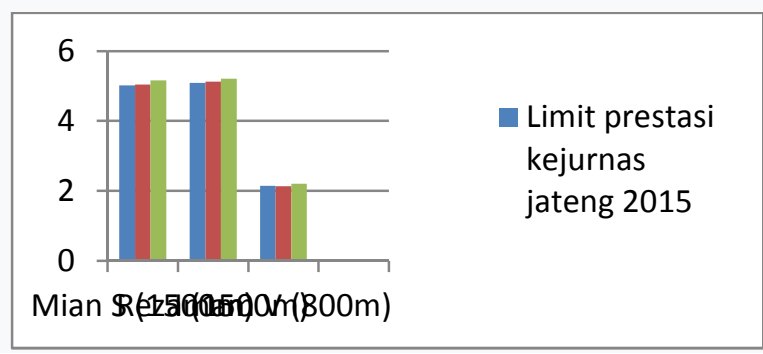

Fig. 2. .Personal Achievement Data Achievement Number Specialists Track Athletes Tuna daksa NPC North Sumatra.
From the graph above it can be seen that the record of personal achievement is decreasing, this can be seen from the curve above. The athlete's performance is decreasing the coach said that the failure in the achievement achievement that has been set is due to psychological factors. The trainer is also aware of the lack of motivation in the individual athlete.

The psychological aspects of athletes are often overlooked by coaches in carrying out training. Though this psychological aspect is very influential on the appearance of athletes. Even if an athlete has prepared physically as well as possible, and has done technical training carefully and optimally. But if there is no or lack of encouragement to achieve the results are often not as expected. Since many tasks must be completed in the future, specifically in training and training that are far behind compared to other countries, now is the time to find solutions to each problem must be fast, careful, and precise.

About the aim of sports coaching, especially for people with disabilities, is to make them more independent in carrying out their daily lives, this is the guiding principle of training conducted in North Sumatra. Especially the physical disabilities that they have are psychic, which makes the trainer work hard to deal with these obstacles.

However, in North Sumatra NPC the trainers were more dominant in providing physical, technical, and strategic training but forgetting the actual mental training was a very important factor. Similarly, at the policy level, sports coaches have not yet considered the psychological aspects of coaching important for athletes.

According to Mappiare (in the 2017 journal) symbolic modeling refers to the image of the view, it can be in the form of images, sculptures, and other forms, from what one wants to emulate in changing behavior; done if the original model is not displayed.

Mungin (2005: 17) says group guidance is a group activity where group leaders provide information and direct discussion so that group members become more social or to help group members achieve common goals.

KholilLurRochman (2010: 104) says anxiety is a subjective feeling of disturbing mental tension as a general reaction to the inability to overcome a problem or lack of security. These erratic feelings generally do not please which will cause or be accompanied by physiological and psychological changes.

Sardiman (2011: 75) states that "motivation is a series of efforts to provide certain conditions, so that someone wants and wants to do something, and if he does not like it, then he will try to uncover or encourage that feeling of dislike". 
Nurdidaya and Selviana (in the 2015 journal) explained that the motivation to excel in sports is an objective possessed by athletes to excel.

\section{RESEARCH METHODS}

The method used in this study is a quantitative method using the Path Analysis approach which uses structural equations that look at the quality dimensions of the influence of symbolic modeling guidance services (X1), group guidance services (X2) anxiety level (Y) on achievement motivation (Z).

Riduwan (2012: 115) explains that the path analysis technique is used in testing the magnitude of contributions (contributions) addressed by the path coefficients in each path diagram of the causal relationship between $\mathrm{X} 1, \mathrm{X} 2$, and $\mathrm{Y}$ with respect to $\mathrm{Z}$. For details can be seen in the following design chart ;

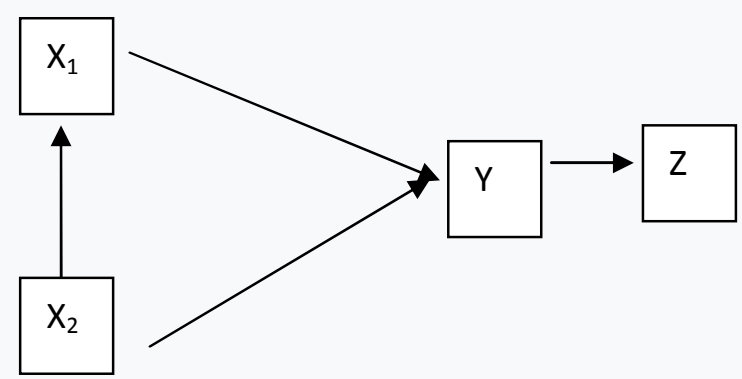

This research site was conducted at the UNIMED Stadium. While the research will be carried out in September 2019.

The study population was all 13 North Sumatra Tunadaksa NPC athletes. The sample in this study amounted to 13 people. The sampling technique used is the "Total Sampling" technique.

The instruments in the study were questionnaires with a scale used in distributing questionnaires / questionnaires to the Likert scale for anxiety and achievement motivation variables.

Data collection techniques in this study were carried out through questionnaires / questionnaires for anxiety and achievement motivation. The collected data was analyzed by path analysis.

\section{RESULTS AND DISCUSSION}

The hypotheses in the discussion of this study are:

1. There is no influence of symbolic modeling guidance services (X1) on anxiety (Y).

2. There is an influence of the influence of symbolic modeling guidance services (X1) on Anxiety (Y).

3. There is no influence of group guidance services $(\mathrm{X} 2)$ on anxiety (Y).
4. There is an influence of group guidance services (X2) on Anxiety (Y).

5. There is no influence of anxiety (Y) on achievement motivation (Z).

6. There is an influence of anxiety (Y) on achievement motivation $(\mathrm{Z})$.

\section{REFERENCE}

[1] Kholil Lur Rochman. 2010. Mental Health. Purwokerto: Fajar Media Press.

[2] Nurdidaya and Selviana.2012.Achievements in Indonesian Paralimpian Sports: Psychological Perspective Study. Journal of Science and Technology Sports 14 (3): 288-308. Ministry of Youth and Sports R.I. Jakarta.

[3] Sardiman 2011.Interaction and Motivation of Teaching and Learning. Jakarta: PT. Raja grafindo Persada.

[4] Sugiyono 2010. Educational Research Methods Quantitative, Qualitative, and R\&D Approaches. Bandung: CV. Alfabeta.

[5] Wibowo, Mungin Eddy. 2005. Development Group Counseling. Semarang: UNNER PRESS 